\title{
Translation and Validation of the "7-Item Eustachian Tube Dysfunction Questionnaire" to European Portuguese (PT)
}

\author{
Tradução e Validação do "7-item Eustachian Tube \\ Dysfunction Questionnaire" (ETDQ-7) para Língua \\ Portuguesa (PT)
}

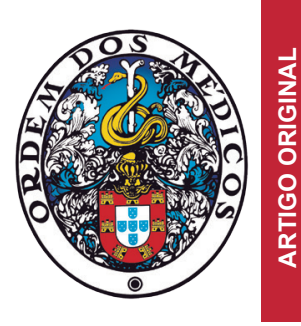

\author{
Ana Sousa MENEZES $\square^{1}$, Daniela Correia RIBEIRO ${ }^{1}$, Joana Rocha GUIMARÃES ${ }^{2}$, Isabel $\operatorname{COSTA}^{1}$, Filipa MOREIRA ${ }^{1}$, \\ Luís DIAS ${ }^{1}$
}

Acta Med Port 2020 Mar;33(3):191-197 • https://doi.org/10.20344/amp.11783

\section{ABSTRACT}

Introduction: Eustachian tube dysfunction is a common cause of morbidity in both adults and children, associated with nasal and otologic symptoms. Symptomatic evaluation is very important for the correct diagnosis and evaluation of the treatment efficacy of this entity. The "7-item Eustachian Tube Dysfunction Questionnaire" was described and validated by McCoul et al and proved to be a useful tool, easy to apply, with good validity in the evaluation of eustachian tube dysfunction symptoms. This study presents the validation process of the European Portuguese version of the "7-item Eustachian Tube Dysfunction Questionnaire". The aim of this study was to translate and validate the European Portuguese version of "Eustachian Tube Dysfunction Questionnaire-7".

Material and Methods: The "7-item Eustachian Tube Dysfunction Questionnaire" was adapted and translated to European Portuguese using standard validation methodology. The European Portuguese version of "7-item Eustachian Tube Dysfunction Questionnaire" was completed by a group of 50 consecutive adult patients diagnosed with eustachian tube dysfunction and 25 healthy patients who served as a control group. All respondents in the Eustachian tube dysfunction group repeated the "7-item Eustachian Tube Dysfunction Questionnaire" in a two week-period. Statistical analysis was performed to determine its psychometric properties (reliability -internal consistency and test-retest reproducibility, and discriminant validity).

Results: Face and content validity were confirmed, and reliability testing revealed similar internal consistency for the entire instrument as the original questionnaire, and strong correlation between individual items and total score. The questionnaire was easy and quick to administer. Test-retest reliability of the European Portuguese version was adequate, with excellent intraclass correlation coefficients and without significant differences between the total score from the first and second evaluations. Discriminative validity was confirmed by statistically significant differences between scores of the test and control groups.

Discussion: This study presents the European Portuguese version of the "7-item Eustachian Tube Dysfunction Questionnaire" questionnaire, an adapted, validated and well-accepted instrument to evaluate the symptoms of eustachian tube dysfunction in the European Portuguese speaking population.

Conclusion: The European Portuguese version of the "7-item Eustachian Tube Dysfunction Questionnaire" is recommended as a routine procedure in the assessment of patients with eustachian tube dysfunction in the European Portuguese speaking population and for the evaluation of treatment outcome.

Keywords: Eustachian Tube; Portugal; Surveys and Questionnaires; Translations; Validation Studies

\section{RESUMO}

Introdução: A disfunção da trompa de Eustáquio é uma patologia comum associada a sintomas nasais e otológicos. A avaliação sintomática desta patologia é importante para o seu correto diagnóstico e avaliação da resposta ao tratamento implementado. O "7-item Eustachian Tube Dysfunction Questionnaire", descrito e validado por McCoul et al, demonstrou tratar-se de uma ferramenta adequada, de fácil e rápida aplicação, com boa reprodutibilidade na avaliação dos sintomas de disfunção da trompa de Eustáquio. Este estudo apresenta o processo validação da versão Portuguesa do "7-item Eustachian Tube Dysfunction Questionnaire". O objectivo deste trabalho foi a adaptação e validação do "7-item Eustachian Tube Dysfunction Questionnaire" para a língua portuguesa.

Material e Métodos: O "7-item Eustachian Tube Dysfunction Questionnaire" foi traduzido e adaptado para língua portuguesa, de acordo com a metodologia recomendada na literatura científica. A versão portuguesa foi aplicada a um grupo teste de 50 doentes consecutivos com o diagnóstico de disfunção da trompa de Eustáquio e a um grupo de controlo de 25 pessoas. Todos os doentes com disfunção da trompa de Eustáquio repetiram o questionário num período de duas semanas. Foi realizada análise estatística para determinar as suas propriedades psicométricas (consistência interna, reprodutibilidade teste-reteste e validade discriminatória).

Resultados: O "7-item Eustachian Tube Dysfunction Questionnaire" traduzido apresentou uma consistência interna similar à do questionário original para cada item e uma forte correlação item-total. A aplicação do questionário foi fácil e rápida. Verificou-se boa reprodutibilidade teste- reteste da versão traduzida do questionário, com excelentes coeficientes de correlação intraclasse e sem diferenças significativas entre o valor total das primeira e segunda medições. A validade discriminatória foi confirmada através da diferença estatisticamente significativa entre a pontuação do grupo teste e grupo controlo.

Discussão: Este estudo demonstra que a versão portuguesa do "7-item Eustachian Tube Dysfunction Questionnaire", é um instrumento adaptado, validado e bem aceite para a avaliação dos sintomas de disfunção da trompa de Eustáquio na população portuguesa.

Conclusão: A versão portuguesa do "7-item Eustachian Tube Dysfunction Questionnaire" é recomendada para o rastreio de disfunção da trompa de Eustáquio na população Portuguesa e para a monitorização da resposta ao seu tratamento.

Palavras-chave: Estudos de Validação; Inquéritos e Questionários; Portugal; Traduções; Trompa de Eustáquio

1. Department of Otorhinolaryngology - Head and Neck Surgery. Hospital de Braga. Braga. Portugal.

2. Department of Otorhinolaryngology. Instituto Português de Oncologia Francisco Gentil. Porto. Portugal.

$\triangle$ Autor correspondente: Ana Sousa Menezes. ana.menezes@hospitaldebraga.pt

Recebido: 06 de janeiro de 2019 - Aceite: 27 de setembro de 2019 | Copyright @ Ordem dos Médicos 2020 


\section{INTRODUCTION}

The Eustachian tube is an osteocartilaginous structure, lined with respiratory ciliated mucosa. It connects the middle ear and the nasopharynx, remaining passively closed with periodic openings. ${ }^{1,2}$ It is responsible for pressure equalisation, ventilation of the middle ear and mucociliary clearance of secretions from the middle ear. It also prevents the retrograde flux of secretions and pathogens from the nasopharynx to the middle ear. ${ }^{1,2}$

Blockage of the Eustachian tube is responsible for tympanic membrane retractions, adhesions, recurrent otitis media with effusion and chronic otitis media. ${ }^{1}$

There are no universally accepted functional tests or scoring systems to diagnose eustachian tube dysfunction (ETD). ${ }^{2}$ Therefore, ETD diagnosis relies at this stage mainly on clinical examination. Symptomatic evaluation is very important to diagnose and to assess disease severity and treatment outcomes. ${ }^{2}$

The "7-item Eustachian Tube Dysfunction Questionnaire" (ETDQ-7) was described and validated by McCoul et al and proved to be an useful tool, easy to apply, with good validity in the evaluation of ETD symptoms. ${ }^{3}$ (Fig. 1) This study presents the validation process of the Portuguese version of the ETDQ-7, to be used as a routine procedure in the assessment of patients with ETD.

\section{MATERIAL AND METHODS}

\section{Questionnaire translation and adaptation}

The translation of the English questionnaire with semantic and content equivalence was obtained from two independent translations by two bilingual physicians, followed by review and reconciliation of the content into a single forward translation. ${ }^{4}$ Afterwards, independent back translations were performed by two English native speakers who were also fluent in Portuguese. These two versions were reconciled into a single version, which was compared with the original questionnaire, and a final consensual translated version was obtained. ${ }^{4}$

A pilot test to assess the content validation of the translated version was carried out in a panel of 20 patients with ETD. Each respondent was asked to answer each question and to comment on clarity, comprehensibility, and ease of use. We observed proper understanding and acceptance, given the absence of doubts during the completion and the availability of patients to participate.

To assess the validity and reliability of the Portuguese version of ETDQ-7, permission was obtained from the corresponding author of the original scale (Anand $\mathrm{V}){ }^{3}$

\section{Psychometric studies}

The study was approved by the Local Ethics Committee (CESHB-13/2017) and was performed according to the principles of the Declaration of Helsinki. All participants included in the study participated voluntarily and were fully informed about its aims, its anonymity and confidentiality. Written informed consent forms were obtained. The final form of the validated Portuguese version of the ETDQ-7 is included in this article (Fig. 2).

\section{Sample and questionnaires ETD group}

Our study involved a convenience sequential sample of 50 outpatients above 18 years-old diagnosed with ETD, followed at our department.

The sample size $(n=50)$ was determined based on the sample of the original study by McCoul et al $(n=50){ }^{3}$

Patients were diagnosed as having ETD if they had a retracted or poorly mobile tympanic membrane on pneumatic otoscopy, with a history of at least two of the following symptoms in one or both ears over the previous one month period: aural fullness or pressure, a sensation of clogged or muffled hearing, recurrent or persistent middle ear effusion (defined as an effusion present on examinations at least

The Seven-Item Eustachian Tube Dysfunction Questionnaire.

\begin{tabular}{|c|c|c|c|c|c|c|c|}
\hline \multirow{2}{*}{$\begin{array}{l}\text { Over the past } 1 \text { month, how much has each of } \\
\text { the following been a problem for you? } \\
\text { 1. Pressure in the ears? }\end{array}$} & \multicolumn{2}{|c|}{ No Problem } & \multicolumn{3}{|c|}{ Moderate Problem } & \multicolumn{2}{|c|}{ Severe Problem } \\
\hline & 1 & 2 & 3 & 4 & 5 & 6 & 7 \\
\hline 2. Pain in the ears? & 1 & 2 & 3 & 4 & 5 & 6 & 7 \\
\hline 3. A feeling that your ears are clogged or "under water"? & 1 & 2 & 3 & 4 & 5 & 6 & 7 \\
\hline 4. Ear symptoms when you have a cold or sinusitis? & 1 & 2 & 3 & 4 & 5 & 6 & 7 \\
\hline 5. Crackling or popping sounds in the ears? & 1 & 2 & 3 & 4 & 5 & 6 & 7 \\
\hline 6. Ringing in the ears? & 1 & 2 & 3 & 4 & 5 & 6 & 7 \\
\hline 7. A feeling that your hearing is muffled? & 1 & 2 & 3 & 4 & 5 & 6 & 7 \\
\hline
\end{tabular}

Figure 1 - Original ETDQ-7 questionnaire, by McCoul et al 


\begin{tabular}{|c|c|c|c|c|c|c|c|}
\hline \multirow{2}{*}{$\begin{array}{l}\text { No último mês, como classifica cada uma das seguintes } \\
\text { situações para si? } \\
\text { 1. Pressão nos ouvidos? }\end{array}$} & \multicolumn{2}{|c|}{ Não é problema } & \multicolumn{3}{|c|}{ Problema Moderado } & \multicolumn{2}{|c|}{ Problema Grave } \\
\hline & 1 & 2 & 3 & 4 & 5 & 6 & 7 \\
\hline 2. Dor nos ouvidos? & 1 & 2 & 3 & 4 & 5 & 6 & 7 \\
\hline 3. Sensação de ouvido entupido ou "debaixo de água"? & 1 & 2 & 3 & 4 & 5 & 6 & 7 \\
\hline 4. Queixas nos ouvidos quando está constipado ou com sinusite? & 1 & 2 & 3 & 4 & 5 & 6 & 7 \\
\hline 5. Estalidos ou crepitação nos ouvidos? & 1 & 2 & 3 & 4 & 5 & 6 & 7 \\
\hline 6. Zumbidos nos ouvidos? & 1 & 2 & 3 & 4 & 5 & 6 & 7 \\
\hline 7. Sensação de audição abafada? & 1 & 2 & 3 & 4 & 5 & 6 & 7 \\
\hline
\end{tabular}

Figure 2 - Validated European Portuguese version of the ETDQ-7 one month apart), or the inability to rapidly self-equilibrate middle ear pressure following changes in ambient atmospheric pressure. Eligibility criteria also included abnormal impedance audiometry at the time of enrollment.

Exclusion criteria included surgery of the head or neck within three months; a history of radiation therapy to the head and neck; sinonasal malignancy; evidence of acute upper respiratory infection, including sinusitis and acute otitis media; adenoid hypertrophy; nasal polyposis; cleft palate or history of cleft palate repair; craniofacial syndrome, including Down syndrome; cystic fibrosis; ciliary dysmotility syndrome; or other systemic immunodeficiency.

All respondents in the ETD group repeated the ETDQ-7 in a two week-period, without treatment during that period, to provide data for analysis of test-retest reliability. The patients agreed not to receive treatment during this period, as most of them were waiting for surgical procedure or had previously tried the medical treatment without improvement. The two-week period was chosen in our study because we believed it would imply a reasonable compromise between recollection bias and clinical change.

\section{Control group}

A second group of 25 volunteers recruited from the hospital staff who did not meet the inclusion criteria were consecutively enrolled as a control group. The size of the control group was based on the original scale design process. ${ }^{3}$ All these volunteers had a normal examination of the tympanic membrane, middle ear, nasal cavity, and nasopharynx. Normal impedance audiometry (type A) was used as a standard criterion to verify the absence of ETD.

\section{Portuguese version of ETDQ-7}

The Portuguese version of ETDQ-7 consists of seven questions, each being scored on a 1 to 7 scale, with a response of " 1 " indicating no problem and " 7 " indicating a severe problem. The higher the score, the worse the severity of symptoms.

Patients were asked if they had pressure, pain in the ears, a feeling of clogged or muffled hearing, ear symptoms during sinusitis or common cold, crackling sounds or tinnitus in one or both ears over the previous one-month period. In this scale, the lowest total score was 7 while the highest was 49.

Questionnaires were self-reported by patients and volunteers, between March and May of 2017. Data were also obtained through medical records in order to confirm the inclusion and exclusion criteria of ETD patients.

\section{Statistical analysis}

The evaluation of the psychometric properties of the questionnaire included the analysis of internal consistency, item - total score correlation and test-retest reliability.

Statistical analysis was performed with the IBM SPSS Statistics program, $22^{\text {nd }}$ version.

Descriptive statistics are presented as frequencies and percentages for categorical variables or as mean \pm standard deviation for continuous variables. Conformity of the data to normal distribution was estimated with the KolmogorovSmirnov test. Internal consistency reliability was assessed using Cronbach's alpha coefficient. Test-retest reliability was evaluated using the intraclass correlation coefficient (ICC). ${ }^{5}$ The qualitative cut-offs for ICC values suggested by Cicchetti (1994) were considered (poor: ICC < 0.40, fair: ICC 0.40 - 0.59, good: 0.60 - 0.74, and excellent: ICC 0.75 - 1.0). ${ }^{6}$ Correlation between each individual item and total ETDQ-7 scores was tested with Pearson or Spearman coefficient when the Pearson's assumptions are not met. ${ }^{7}$ Discriminative validity was evaluated by comparison between scores of the test and control groups with independent sample $t$ test. Significance was settled for $p<0.05$.

\section{RESULTS \\ Descriptive analysis \\ Subjects}

A total of 75 patients were enrolled for the validation of the study meeting the study eligibility criteria for ETD and control groups. Fifty subjects had a diagnosis of ETD, and 
Table 1 - Scores obtained in the ETDQ-7 questionnaire in the ETD group $(n=50)$

\begin{tabular}{|c|c|c|}
\hline Items & Mean \pm SD & Median \\
\hline $\begin{array}{l}\text { 1. Pressão nos ouvidos? } \\
\text { 1. Pressure in the ears? }\end{array}$ & $3.88 \pm 1.66$ & 4 \\
\hline $\begin{array}{l}\text { 2. Dor nos ouvidos? } \\
\text { 2. Pain in the ears? }\end{array}$ & $2.80 \pm 1.78$ & 2 \\
\hline $\begin{array}{l}\text { 3. Sensação de ouvido entupido ou "debaixo de água"? } \\
\text { 3. A feeling that your ears are clogged or "under water"? }\end{array}$ & $4.94 \pm 1.74$ & 5 \\
\hline $\begin{array}{l}\text { 4. Queixas nos ouvidos quando está constipado ou com sinusite? } \\
\text { 4. Ear symptoms when you have a cold or sinusitis? }\end{array}$ & $4.69 \pm 2.06$ & 5 \\
\hline $\begin{array}{l}\text { 5. Estalidos ou crepitação nos ouvidos? } \\
\text { 5. Crackling or popping sounds in the ears? }\end{array}$ & $4.35 \pm 1.90$ & 5 \\
\hline $\begin{array}{l}\text { 6. Zumbidos nos ouvidos? } \\
6 . \text { Ringing in the ears? }\end{array}$ & $5.10 \pm 1.69$ & 6 \\
\hline $\begin{array}{l}\text { 7. Sensação de audição abafada? } \\
\text { 7. A feeling that your hearing is muffled? }\end{array}$ & $5.27 \pm 1.57$ & 6 \\
\hline Total & $30.86 \pm 6.84$ & 32 \\
\hline
\end{tabular}

25 patients served as a control group.

\section{ETD group}

The mean age in the ETD group was $51.16 \pm 14.47$ years, ranging from 18 to 57 years. There were 21 males (42\%) and 29 females (58\%). All subjects meeting inclusion criteria for ETD were found to have an abnormal tympanogram.

\section{Control group}

The mean age in the control group was $34.90 \pm 9.84$ years, ranging from 26 to 65 years. There were 6 males $(24 \%)$ and 19 females (76\%). All subjects in this group had bilateral type A tympanometry curve tracings.

\section{Questionnaire}

All patients completed all items of the questionnaire without difficulty, with an average time of response $1.35 \pm$ 0.8 minutes.

The items with the highest score in the ETD group were item 7 ("A feeling that your hearing is muffled?"), item 3 ("A feeling that your ears are clogged or "under water?") and item 4 ("Ear symptoms when you have a cold or sinusitis?"). The lowest score was detected for item 2 ("Pain in the ears?") (Table 1).

The mean total score in the ETD group was $30.86 \pm$ 6.84 , with a minimum score of 16 and a maximum of 44 . On the other hand, in the control group, the mean total score was $8.81 \pm 2.09$, with a minimum of 7 and a maximum of 15 .

\section{Internal consistency reliability}

Internal consistency reliability testing of the ETDQ-7 yielded a Cronbach alpha of 0.896 (very high) for the entire instrument (Table 2).

\section{Item-total correlation}

The item-total correlation was above 0.4 in all items of the questionnaire (Table 2).

\section{Test-retest reliability}

All patients with ETD repeated the questionnaire in an untreated state two weeks after the initial visit. Patients did not receive any medical or surgical intervention during the intervening period.

There was an excellent test-retest reliability for the validated Portuguese version of the ETDQ-7 Questionnaire. The ICC coefficient was above 0.8 for all items (ranging from 0.836 to 0.944 ) and there was a strong correlation between the first and second evaluations for each item of the questionnaire (Pearson correlation coefficient between 0.724 and $0.897 ; p<0.01)^{7}$ (Table 3 ). There were no statistically significant differences between the first and second evaluation scores for each item of the questionnaire $(p>0.05)$, except for Item 2 ("Pain in the ears?") (Table 4). When the five patients who had an increase equal or higher than two point in the score of item 2 between observations were excluded from the analysis, one could see that there were no significant differences between the two evaluations (mean score of the first evaluation of item 2: $2.80 \pm 1.779$; second evaluation $2.93 \pm 1.709$ )

\section{Discriminant validity}

In order to assess the ability of ETDQ-7 to differentiate between the patients with and without ETD, the scores between the test and control groups were compared. The total

Table 2 - Internal consistency reliability and item-total score correlation testing of the ETDQ-7

\begin{tabular}{lcc}
\hline Items & $\begin{array}{c}\text { Cronbach's Alpha } \\
\text { if item deleted }\end{array}$ & $\begin{array}{c}\text { Item-total score } \\
\text { correlation }\end{array}$ \\
\hline Item 1 & 0.880 & 0.714 \\
Item 2 & 0.899 & 0.517 \\
Item 3 & 0.871 & 0.779 \\
Item 4 & 0.881 & 0.700 \\
Item 5 & 0.872 & 0.774 \\
Item 6 & 0.883 & 0.683 \\
Item 7 & 0.877 & 0.728 \\
\hline
\end{tabular}


Table 3 - Test-retest reliability -Intraclass correlation (ICC) and Pearson correlation coefficients for each item

\begin{tabular}{lcccc}
\hline Items & ICC coefficient & 95\% Confidence Interval & Pearson Correlation & $\boldsymbol{p}$ \\
\hline Item 1 - Retest Item 1 & 0.855 & $0.735-0.920$ & 0.761 & $<0.001$ \\
Item 2 - Retest Item 2 & 0.907 & $0.809-0.952$ & 0.853 & $<0.001$ \\
Item 3 - Retest Item 3 & 0.891 & $0.805-0.940$ & 0.818 & $<0.001$ \\
Item 4 - Retest Item 4 & 0.944 & $0.898-0.969$ & 0.897 & $<.001$ \\
Item 5 - Retest Item 5 & 0.836 & $0.705-0.909$ & 0.724 & $<0.001$ \\
Item 6 - Retest Item 6 & 0.861 & $0.750-0.923$ & 0.759 & $<0.001$ \\
Item 7 - Retest Item 7 & 0.851 & $0.733-0.918$ & 0.743 & $<0.001$ \\
Test Total - Retest Total & 0.932 & $0.76-0.963$ & 0.877 & $<$ \\
\hline
\end{tabular}

Table 4 - Comparison of test-retest item score means

\begin{tabular}{lcccc}
\hline Items & Test score & Retest score & $\boldsymbol{t}$ & $\boldsymbol{p}$ \\
\hline Item 1 & $3.88 \pm 1.66$ & $4.26 \pm 1.81$ & 2.059 & 0.055 \\
Item 2 & $2.80 \pm 1.78$ & $3.22 \pm 1.85$ & 3.006 & 0.004 \\
Item 3 & $4.94 \pm 1.74$ & $4.78 \pm 1.50$ & 1.000 & 0.323 \\
Item 4 & $4.69 \pm 2.06$ & $4.70 \pm 1.91$ & 0.628 & 0.533 \\
Item 5 & $4.35 \pm 1.90$ & $4.59 \pm 1.65$ & 0.774 & 0.443 \\
Item 6 & $5.10 \pm 1.69$ & $5.22 \pm 1.55$ & 0.771 & 0.445 \\
Item 7 & $5.27 \pm 1.57$ & $5.15 \pm 1.48$ & 1.091 & 0.281 \\
Test Total & $30.86 \pm 6.84$ & $32.11 \pm 6.89$ & 1.654 & 0.105 \\
\hline
\end{tabular}

Table 5 - Comparison of ETD and control groups' item scores

\begin{tabular}{lcccc}
\hline Items & $\begin{array}{c}\text { ETD group score } \\
(\mathbf{n}=\mathbf{5 0})\end{array}$ & $\begin{array}{c}\text { Control group score } \\
(\mathbf{n}=\mathbf{2 5})\end{array}$ & $\boldsymbol{t}$ & $\boldsymbol{p}$ \\
\hline Item 1 & $3.88 \pm 1.66$ & $1.14 \pm 0.48$ & 10.522 & $<0.001$ \\
Item 2 & $2.80 \pm 1.78$ & $1.00 \pm 0.00$ & 7.065 & $<0.001$ \\
Item 3 & $4.94 \pm 1.74$ & $1.33 \pm 0.73$ & 12.050 & $<0.001$ \\
Item 4 & $4.69 \pm 2.06$ & $1.81 \pm 0.98$ & 7.737 & $<0.001$ \\
Item 5 & $4.35 \pm 1.90$ & $1.24 \pm 0.54$ & 10.514 & $<0.001$ \\
Item 6 & $5.10 \pm 1.69$ & $1.10 \pm 0.44$ & 15.468 & $<0.001$ \\
Item 7 & $5.27 \pm 1.57$ & $1.10 \pm 0.44$ & 17.161 & $<0.001$ \\
Test Total & $30.86 \pm 6.84$ & $8.81 \pm 2.09$ & 20.447 & $<0.001$ \\
\hline
\end{tabular}

ETDQ-7 score among the 50 patients in the ETD group was significantly higher compared to the score among the 25 patients in the control group $[t(73)=20.447, p<0.001, d$ $=4.359$ ) (Table 5). The mean total score in the ETD group was 30.86 ( \pm 6.84$)$ compared with 8.81 ( \pm 2.09$)$ in the control group. The mean individual score for each of the seven items of the ETDQ-7 was also significantly greater for the ETD group compared to the control group $(p<0.001)$ (Table 5).

\section{DISCUSSION}

ETD is a frequent pathological entity that may carry great morbidity to patients and a negative impact on patients' quality of life. The need for a validated, disease-specific instrument for ETD is particularly notable because of the lack of a widely accepted objective measure of the presence and severity of this disorder. ${ }^{2,3}$

In 2012, McCoul et al developed and validated the ETDQ-7 questionnaire for the evaluation of chronic ETD symptoms, in an attempt to improve patient management and follow-up. ${ }^{3}$

This disease-specific instrument for ETD allows the quantitative measurement of subjective questions, which is important for formal and valid documentation of patient history as well as for record and subsequent comparisons after the implementation of treatment. Furthermore, this scale has potential usefulness for outcomes research in the study of patients with ETD.

The ETDQ-7 has been translated, validated and adapted to German, Turkish and Brazilian Portuguese, also with similar results to the original North-American version, and it is strongly suggested as an adjunct method for the diagnosis and management of patients with chronic ETD. ${ }^{8-10}$

The current study aimed to translate, validate and culturally adapt the ETDQ-7 questionnaire into European Portuguese.

The internal consistency reliability testing of the Portuguese ETDQ-7 yielded a high Cronbach alpha (0.896) for 
each item. ${ }^{11}$ An internal consistency evaluation after the elimination of each item did not substantially improve the observed internal consistency and, as a result, no items were added or removed from the tool. The high score of Cronbach alpha in our study shows that the items in the questionnaire are inter-related and that the construction of the instrument is homogeneous. On the other hand, this high score observed in our study might imply redundancy of some items from the questionnaire, which means that some items may evaluate the same symptom.

In our study, there was a strong correlation between individual items and total score. Item-total correlation exceeded the minimum acceptable value of 0.4 which represents an adequate item-total consistency. ${ }^{11}$

Test-retest reliability of the Portuguese version was adequate with an ICC coefficient superior to 0.8 for all items. Also, there was a strong correlation between the first and second evaluations for each item of the questionnaire and there were no differences between the total value from the first and second evaluations, except for item 2. It is not clear the reason for this difference between observations for item 2 ("Pain in the ears?"). However, after the exclusion of the five patients who had a two-point or more increase in the score of item 2 between observations from the analysis, one can see that there are not significant differences between the two evaluations. Also, besides the symptom of pain in the ears not being specific of ETD, it is possible that these patients had a modification of their status between the two evaluations. Nevertheless, the difference encountered is minor and might have been insignificant if our sample was larger.

In the original study, the retest of patients one month later showed good test-retest reliability, with the retest in patients with chronic ETD, showing a Spearman's correlation coefficient of 0.78 . Like in the original study, patients did not receive any medical or surgical intervention during the intervening period.

The items with the highest score in the ETD group were item 7 ("A feeling that your hearing is muffled?"), item 3 ("A feeling that your ears are clogged or "under water?") and item 4 ("Ear symptoms when you have a cold or sinusitis?"). The lowest score was detected for item 2 ("Pain in the ears?") which was the only item with a slight difference between the test and retest value.

Discriminative validity was confirmed by statistically significant differences between scores of the test and control groups. The original study has presented a cut-off point in the ETDQ-7 of $\geq 14.5$ vs $<14.5$, to discriminate between

\section{REFERENCES}

1. Dornhoffer JL, Leuwer R, Schwager K, Wenzel S. Physiology of the Eustachian tube. In: Dornhoffer JL, Leuwer R, Schwager K, Wenzel $\mathrm{S}$, editors. A Practical Guide to the Eustachian Tube. Berlin: Springer; 2014. p.13-6.

2. Schilder AG, Bhutta MF, Butler CC, Holy C, Levine LH, Kvaerner KJ, et al. Eustachian tube dysfunction: consensus statement on definition, types, clinical presentation and diagnosis. Clin Otolaryngol. 2015;40:407-11.

3. McCoul ED, Anand VK, Christos PJ. Validating the clinical assessment of eustachian tube dysfunction: the Eustachian Tube Dysfunction the patient and non-patient groups, with sensitivity and specificity of $100 \%$. In our study, for all patients with ETD, total scale scores were observed to be greater than 14.5 as was stated as a threshold in the study by McCoul et al. Moreover, only one patient of our control group had total scale scores greater than 14.5 which corroborate the ability of the ETDQ-7 to discriminate between the patient and nonpatient groups.

This tool was already translated and validated to other languages and we believe that the application of this instrument in the European Portuguese speaking population will be important for clinical practice.

\section{CONCLUSION}

In conclusion, this study presents the Portuguese version of the ETDQ-7 questionnaire, an adapted, validated and well-accepted instrument to evaluate the symptoms of ETD in the European Portuguese speaking population. This tool can be especially valuable in follow-up examinations, to measure the outcome of medical and surgical treatment of patients with ETD and for the comparison of results with the international literature.

\section{OBSERVATIONS}

This study was presented at the 64th Congresso Nacional da Sociedade Portuguesa de Otorrinolaringologia e Cirurgia Cérvico-Facial which took place on 5 to 7 May 2017, at Viana do Castelo.

\section{PROTECTION OF HUMANS AND ANIMALS}

The authors declare that the procedures were followed according to the regulations established by the Clinical Research and Ethics Committee and to the Helsinki Declaration of the World Medical Association.

\section{DATA CONFIDENTIALITY}

The authors declare having followed the protocols in use at their working center regarding patients' data publication.

\section{CONFLICTS OF INTEREST}

All authors report no conflict of interest.

\section{FUNDING SOURCES}

This research received no specific grant from any funding agency in the public, commercial, or not-for-profit sectors.

Questionnaire (ETDQ-7). Laryngoscope. 2012;122:1137-41.

4. Wild D, Grove A, Martin M, Eremenco S, McElroy S, Verjee-Lorenz A, et al. Principles of good practice for the translation and cultural adaptation process for Patient-Reported outcomes (PRO) Measures: report of the ISPOR Task Force for translation and cultural adaptation. Value Health. 2005;8:94-104.

5. Streiner DL, Norman GR. Health measurement scales. A practical guide to their development and use. $5^{\text {th }}$ ed. New York: Oxford University Press; 2003. 
6. Cicchetti D. Guidelines, criteria, and rules of thumb for evaluating normed and standardized assessment instruments in psychology. Psychol Assess. 1994;6:284-90.

7. Bryman A, Cramer D. Quantitative data analysis with IBM SPSS 12 and 13: a guide for social scientists. New York: Routledge, Taylor and Francis Group; 2005.

8. Schröder S, Lehmann M, Sudhoff H, Ebmeyer J. Assessment of chronic obstructive Eustachian tube dysfunction: evaluation of the German version of the Eustachian Tube Dysfunction Questionnaire. HNO. 2014;62:160-4.
9. Özgür E, Bilgen C, Cengiz Özyurt B. Turkish validity and reliability of Eustachian tube dysfunction questionnaire-7. Braz J Otorhinolaryngol. 2018:84:435-40.

10. Gallardo FP, Ornishi ET, Lira FI, Suzuki FB, Testa JR. Translation, validation and cultural adaptation of "The Eustachian Tube Dysfunction Questionnaire-7" (ETDQ-7) to Brazilian Portuguese (BR). Braz J Otorhinolaryngol. 2019;85:456-64.

11. Tavakol M, Dennick R. Making sense of Cronbach's alpha. Int J Med Educ. 2011;2:53-5. 